\title{
MORPHOLOGICAL AND PHENOTYPE ANALYSIS OF MICROSYMBIONT AND BIOMASS MARINE SPONGE FROM MELAWAI BEACH, BALIKPAPAN, EAST KALIMANTAN
}

\author{
Ismail Marzuki'; Alfian Noor ${ }^{2}$, Nursiah La Nafie ${ }^{2}$, M. Natsir Djide ${ }^{3}$ \\ ${ }^{I}$ Departement of Chemical Engineering, Faculty of Engineering, Fajar University \\ ${ }^{2}$ Department of Chemistry, Faculty of Mathematics and Natural Sciences, Hasanuddin University \\ ${ }^{3}$ Department of Pharmacy, Faculty of Pharmacy, Hasanuddin University \\ E-mail : ismailmz3773@gmail.com
}

\begin{abstract}
Determination biomass and phenotypic analysis of microsymbionts sponge is a comprehensive effort to discover the specificity of the sponge, not only on the identification and characterization studies that have been growing. Research directed at diversification of knowledge of the functions and benefits of a sponge for the life and welfare of mankind. The purpose of this research is the analysis of biomass morphology and phenotype test microsymbionts sponge. Histomorfologi analysis method to determine the type, components and composition biomass. Isolates obtained by sponge microsymbiont isolationpurification followed by phenotypic analysis through Gram staining and biochemical tests. Histomorfologi analysis results obtained sponge species is Callyspongia sp. Components and composition consists of sponge biomass fraction skeleton (spicules and cell debris) reached $69.8 \%, 18.8 \%$ sponge cell fraction and $11.3 \%$ bacterial pellet fraction. The results of the isolation-purification microsymbiont obtained two isolates. Staining test results both isolates are Gram-positive bacteria and biochemical tests is Bacillus subtilis isolates the spherical shape large size, beige and white, while the isolates two clustered colonies are bacillus flexus jagged shape elongated, white-purple color and a separate colony.
\end{abstract}

Keywords: histomorfologi, phenotype, Callyspongia sp, biomass, microsymbiont, sponge

\section{INTRODUCTION}

Potential sea sponge Indonesia reached $80 \%$ of sponge world, is one of the natural wealth that must be preserved in order to remain part of the marine ecosystem to ensure the balance of marine life. Exploration sponge until now only at the stage of identification reach species of the estimated 3,500 species of sponges Indonesia. Knowledge of the sponge more specific about the functions and benefits have been conducted on a small scale and a limited amount of such research on the content of metabolic both primary and secondary sponge that can lead to the discovery of raw materials potential drug, (Kim et al., 2006), the function of sponge as absorbent microsymbiont heavy metal and sponge as material to degrade hydrocarbons, (Marzuki et al., 2014; Lydia et al., 2014; Netty et al., 2013; Syakti et al., 2013; Shama et al., 2010).

Sponges are multicellular metazoan animals, (Bergquist, 2001), which are filter feeders porous, so it becomes a habitat for microorganisms to nest in them, (Steindler et al., 2002). Symbiont microorganisms has two important roles in biological systems sponge, first as a food source either by microorganisms or by sponge second microsymbiont make the sponge as a host for the life of microorganisms and sponges utilize microsymbiont as a defense in order to adapt and survive in extreme environments (environment polluted hydrocarbons and heavy metal), (Netty et al., 2013; Steindler et al., 2002; Zocchi et al., 2002; Friederich et al., 1999; Vacelet et al., 1977).

Some types of bacteria can symbionts including symbiosis with sponge sponge Theonella $s p$ with stepylococcus aureus, (Marzuki et al., 2015a; Hentschel et al., In Mahdiyah et al., 2012; Murniasih et al., 2010). Bacteria is a microorganism commonly found symbiont with a sponge. It is estimated that up to $40 \%$ biomass several species of sponges prepared by the bacterial community, (Murniasih et al., 2010; Thakur, 2004). Some unidentified indigenous bacteria could degrade petroleum sludge, (Marzuki et al, 2015; Syakti et al., 2013; Li et al., 2012).

Some types of marine bacteria known to degrade components of aromatic hydrocarbons high toxicity by utilizing components of PAH as a source of carbon and energy, (Gan et al., 2009; Murniasih et al., 2009), the type of dominant bacteria are Enterobacter sp., Bacillus sp., Clostridium sp., Pseudomonas sp., Aeromonas sp and Citrobacter sp., (Yani et al., 2012; Gan et al., 2009; Tam et al., 2008; Ekpo et al., 2008). Bacillus group of bacteria that degrade components of aromatic compounds, among others: Bacillus macerans, B. mycoides, B. megaterium, B. subtilis, 
B. pumilus, B. thermoleovorans, B. gordonae, and B. benzoevorans, (Marzuki et al., 2015; Obire et al., 2011; Gan et al., 2009; Lin et al., 2008; Liu et al., 2007).

Melawai beach Balikpapan including tidal beach, a tourist destination and culinary visited by many people not only see the sunset but as a means to enjoy two of the island coast of the island of Twins Tukung and enjoying traffic transport tanker, freighter, (Marzuki et al., 2014; Jayardana, 2006).

The research objective to analyze the morphology, biomass determination, isolationpurification, identification of microbial symbionts sponge Melawai Beach from Balikpapan East Kalimantan is expected to be new information about the type of sponges, biomass and microsymbiont. This research includes the identification of species of sponges through morphological analysis, determination of sponge cell biomass components, isolation-purification and analysis of phenotypic methods gram staining and biochemical tests microsymbiont.

\section{RESEARCH METHODS}

\section{The materials and equipment}

Sponges from Melawai Beach Balikpapan, $\mathrm{CH} 3 \mathrm{OH}$ pa, Seawater sterile Phosphate Buffer Saline (PBS), Sea Water Complit (SWC), Media NA, marine agar (MA), 25\% glycerol, bacteria, $\mathrm{NaCl} 0.9 \%$ formalin 4\%, Aqubides, distilled, reagent $\mathrm{MTT}, \mathrm{KCl}, \mathrm{MgCl} 2$, DMSO.

Some of the tools used as Scuba, a camera in the water, GPS, Tray, scalpels, tweezers, jars, plastic bags, boxes of ice, Set phase contrast microscope, porcelain dish, mortar and pestle, blender, sets of glassware, bunsen, stir bar, analytical balance, hot plate, a rubber suction, Whatman, oven, freezer, BOD bottles, thermometers, ose round, straight ose, ose disposable, test tubes, effendorf $1.5 \mathrm{~mL}$ tubes, petri dish, tube racks, vortex shaker, centrifugation, spoon media, magnetic stirrer, a container compactor gel, universal paper, salinometer, stop watch, laminary air flow (LAF), glass prevarat, autoclove, $0.2 \mathrm{~m}$ filter, phase contrast microscope haemositometer.

\section{Time and Place Research}

When the study for six months in 2015. The research in the Laboratory of Microbiology Pharmacy Faculty of Pharmacy and Biochemistry Laboratory, Department of Chemistry, F.MIPA University of Hasanuddin.

\section{Samples and Sampling Location}

Potential sponge obtained from East Kalimantan Balikpapan Melawai Beach at coordinates $01^{0} 16$. $36^{\prime} 8$ "LS and $116^{\circ} 48.23^{\prime} 6^{\prime \prime} \mathrm{E}, 29^{\circ} \mathrm{C}$ sea water temperature, salinity $30 \%$, $\mathrm{pH} 7$ and sampling depth of $2.7 \mathrm{~m}$. Sponge lifted to the surface of the sea, then do pemotre- tan, partly spongy tissue is taken, his next put in 5\% marine broth medium to be isolated (direct plating method).

\section{Analysis method}

The method of analysis carried out in five phases of work, namely: 1) analysis histomorfologi; 2) the determination of the components and composition of biomass; 3 ) the isolation-purification microsymbiont 4) characterization by gram staining; 5) biochemical test.

\section{Morphological Analysis sponge \\ Identification sponge made with} morphological analysis sponge (color, texture, shape, size and depth of seawater during the sampling and analysis histomorfologi cell sponges under a microscope with MTT method, assay, (A) cell culture prior to treatment $24 \mathrm{~h}$ incubation begins after 4 hours Extra MTT reagent, (B) control cells (C) sponge extract concentration of $960 \mathrm{ug} / \mathrm{mL}$, (D) extract concentration of 7.5 ug/mL, (E) control DMSO, (Hooper, 1997).

\section{Determination and sponge biomass composition}

Sponge biomass is determined by cutting one part of the sponge, put in $4 \%$ formalin, diluted with sterile sea water that has been filtered with a $0.2 \mathrm{~m}$ filter, and then in the blender, the suspension was taken and centrifuged at $1000 \mathrm{rpm}$ for $5 \mathrm{~min}$, the supernatant was taken and back centrifuged at $5000 \mathrm{rpm}$ for 10 minutes, the fraction. Each fraction was weighed to determine the outcome centrifugation weight (\%), (Ismet et al., 2011).

\section{Isolation and purification of microsymbionts sponge}

Sea sponges have been identified in histomorfologi. Selected one bud sponge subsequently isolated by means of the surface of the sponge sprayed using sterile sea water with a ratio of $1 \mathrm{~cm}^{2}$ sponge size: $5 \mathrm{~mL}$ of sterile sea water, so that only the bacteria by combining powerful which will sampling. Part mesohyl sponge taken with $\pm 1 \times 1 \mathrm{~cm}$ size, crushed and 
diluted with Phosphate Buffer Saline (PBS) sterile in the ratio 1:1, (Kim et al., 2006).

Isolation of bacteria using a sterile swab, (Wahl et al., 1994), which is rubbed with a direction on the outer surface of the sponge. Sterile swab that has been rubbed on the surface of the sample is introduced into the dilution tube containing sterile PBS and vorteks. Dilution deployed into a petri dish that already contains media Sea Water Complit (SWC) with the composition of 1 liter of medium consisting of 5 $\mathrm{g} / \mathrm{L}$ bacto peptone, $1 \mathrm{~g} / \mathrm{L}$ yeast extract and $3 \mathrm{~mL} / \mathrm{L}$ glycerol, and incubated at $30{ }^{\circ} \mathrm{C}$ for $24-36$ hours, the observed growth of the colony. Each bacterial colonies growing observed morphology, namely the color, size and shape of the colony. Colonies that grew dominant separated to be isolated and purified by using the same media.

In direct plating methods, observed colonies that grow after incubation for one to two weeks, then colonies of different shapes and colors isolated. Each colony do purification, namely by scraping 1 ose colonies directions zigzagging on a petri dish containing media $100 \%$ marine so then incubated at $30^{\circ} \mathrm{C}$ for $1-2$ days. After growing new colonies do etching reset at $100 \%$ marine media in order to obtain a single colony. The number of colonies counted, the results are stored purification using $25 \%$ glycerol in marine media order, (Kurniawan, 2012; Murniasih et al., 2009; Djide et al., 2008).

\section{Analysis of Bacterial symbionts phenotype sponge}

Characterization microsymbiont through the process of identification of Gram staining and biochemical tests. The process is done by taking a gram stain of bacteria 1 ose on glass objects that have previously been relieved of fatty acid free with $96 \%$ alcohol, then used as drops of crystal violet (Gram A) 1-3 drops, made undelete, silenced then washed using distilled water and then dried, then spilled Lugol (Gram B) 1-3 drops, made undelete, silenced, then, washed and dried, and then a few drops of alcohol acetate (Gram C) 1-3 drops then made undelete, silenced, and washed using distilled water, dried, and then spilled safranin (Gram D), made undelete, allowed to stand, and then washed using distilled water and dried, and then observed under a microscope at 10x magnification, then etched with $\mathrm{KOH} 1 \%$, stirred and observed the formation of mucus, (Kurniawan, 2012; Lay, 1994).
Biochemical test standard consisted of 15 test parameters on the appropriate medium consisting of hydrolysis test starch, hydrolyzed casein, reaction indole, reduction of nitrite, fermentation of glucose, lactose fermentation, the fermentation of sucrose, fermentation mannitol, test citrate, catalase test, test urease, test $\mathrm{H}_{2} \mathrm{~S}$, methyl red test, test and test Voges Proskauer gelatin. Indicators observations by looking at the change in color, turbidity or sediment in the media which showed the reaction, (Kurniawan, 2012).

\section{RESULTS AND DISCUSSION}

\section{Analysis sponge of histomorfology}

Sponges origin Melawai Beach Balikpapan after histomorfology analysis in the form of a sponge formed massiva growth and oscula scattered along the surface of the sponge body, it became apparent after staining in $\mathrm{EtOH}$ and enlarged, (picture. 1: a,b,c,d).

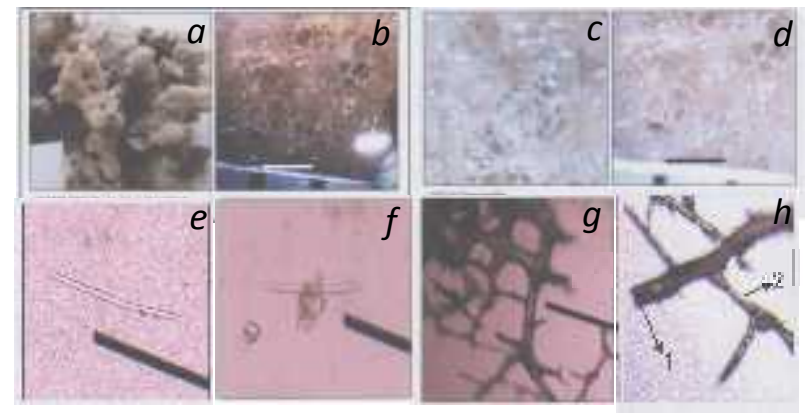

Pic. 1 The results of the analysis of the sponge histomorfologi: species Callyspongia sp. a) growth form massiva, oscula scattered along the surface of the sponge body; b) the results of staining with $\mathrm{EtOH}$; c) the results compress texture; d) the surface structure after zooming; e) megascleres Axea be tangent with various sizes; f) does not have microscleres and spicula relatively low; g) the structure of the skeleton is irregular and contains spongin; h) skeleton consists of two parts, namely the main skeleton (no.1) and skeleton fibers (no. 2). skeleton manifold isodictyal that make some spicula. Type spicula form of puni-pauci.

The structure of the sponge were observed on preparations histology, looked megascleres Axea be tangent with various sizes, have microscleres and spicula relatively low, skeleton irregular and contain spongin consists of the main part and the curly part, (pic 1, e, f, gh), Based on this it was concluded that the sponges are identified by species Callyspongia $s p$, family Callyspongiidae, class Demospongiae, (Marzuki et 
al., 2015; Ismet et al., 2011; Thakur, 2004; Duchassaing, 1964).

Sponge structure has at least spicules and skeleton contains debris or spongin, sponge cells and possibly some microsymbiont, (Ismet et al., 2011; Gazave, 2010; Bergquist, 2001; Ruppert et al., 2004).

2. Components and sponge cell biomass composition Callyspongia sp

Analysis sponge biomass consists of determining the composition of components and measurement of the fraction of the sponge cells Callyspongia $s p$. derived component skeleton (spicules and cell debris) reached $69.8 \%$, the fraction of sponge cells (choanosome) $18.8 \%$ and $11.3 \%$ of bacteria pellets. The composition of the cell fraction sponge Callyspongia sp shows that biomass is dominated by the skeleton, where the skeleton component is dominantly influenced by morphology. Morphological structure of the sponge spicules and debris fractions containing spongin so dominant that causes morphological Callyspongia $s p$ more rigid sponge containing spicules solid despite not having microscleres. Low bacterial pellet fraction indicates that the sponge containing bacterial symbionts only slightly, as an indicator that Callyspongia sp living in the area that is fertile and rich in organic matter, (Nugroho, 2006). Cell high biomass content but contains very little bacterial symbionts available enough nutrients for growth, so that the symbiont microbes (bacteria) is not needed in the mechanisms of physiological adaptation sponge. These results are consistent with the results of histology-morphological observations of the sponge Callyspongia sp, (Ismet et al., 2011; Setyadji et al., 2010; Ruppert et al., 2004; Bergquist, 2001). These results suggest that environmental threats to life, especially Callyspongia $s p$ sponge. existing in Balikpapan Melawai Beach is not too extreme. An abundance of sponge cell biomass is strongly influenced by temperature, climate, organic substances, and the rate of photosynthesi, (Steindler et al., 2002; Zocchi et al., 2002). Noting composition Callyspongia sp sponge cell biomass obtained, it can be predicted that the number and type of microsymbiont on the sponge is not abundant and unlimited variations, (Marzuki et al., 2014; Murniasih et al., 2010; Thakur, 2004;).

3. Results Isolation and purification of bacterial symbionts Callyspongia sp sponge.

Macroscopic analysis of the isolated bacterial symbionts Callyspongia $s p$ sponge, the colors, textures, shapes, size and number of colonies, as well as the depth at the time of sampling sponge observation indicator in determining the type of microsymbiont.

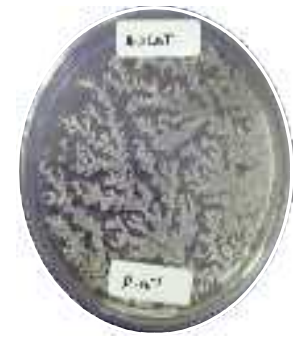

a

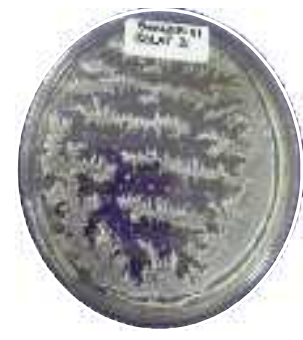

b
Pic. 2 Two isolates sponge symbiont Callyspongia sp a) large round shape, the color of creamywhite, clustered colonies, b) a jagged shape elongated, white-purple color, a separate colony.

Colonies of bacteria were obtained for isolation and purification of a colony which grew dominant. The second identified colonies can grow well in dilution $10^{-2}$ to $10^{-4}$. Microscopic identification and purification of the isolated sponge of Callyspongia sp obtained only two isolates. Isolates first with characteristic rounded shape large, creamy-white, colonies huddled together, hereinafter referred isolates first, and isolates both the characteristics of the shape of jagged, elongated, white, purple, separate colony, called isolates 2, (Hooper, 1997). The results of the isolation and purification of bacterial symbionts obtained two isolates, it is reasonable and in accordance with the composition and type of biomass components were dominated by the skeleton (spicules and cell debris), then the cell sponge and a little pellet bacteria and morphological observation Callyspongia $s p$ of sponge, (Marzuki et al., 2014; Ismet et al., 2011; Silberhorn et al., 2007).

4. Analysis of the phenotype of bacterial symbionts sponge

Analysis of the phenotype characterization of isolates carried both Gram staining and biochemical tests after pure isolates obtained. Observation 1 microscopic isolates and isolates 2 after staining gram by characteristics observed, (Table 1), indicating that the two isolates are grampositive bacteria. 
Table 1 Results of microscopic analysis microbia symbionts gram staining sponge Callyspongia sp

\begin{tabular}{lll}
\hline \multicolumn{1}{c}{ Observation } & Isolates of 1 & Isolates of 2 \\
\hline color & Blue-purple & purple \\
form & stem & Basil \\
Reagent Safranin & Fixed color & Color stays \\
Endospores & there, & there, \\
& less clear & less clear \\
Alkali $(1 \% \mathrm{KOH})$ & insoluble & insoluble \\
\hline Conclusions & gram-positive & gram-positive \\
\hline
\end{tabular}

Table 2 Results of biochemical test isolates 1 and 2 Callyspongia $s p$ of sponge bacterial symbionts

\begin{tabular}{|c|c|c|c|}
\hline \multirow[b]{2}{*}{ Biochemistry Test } & \multirow[b]{2}{*}{ Media } & \multicolumn{2}{|c|}{ Reactio } \\
\hline & & $\begin{array}{c}\text { Isolates } \\
\text { Of } 1\end{array}$ & $\begin{array}{l}\text { Isolates } \\
\text { of } 2\end{array}$ \\
\hline Starch Hydrolysis & starch & + & + \\
\hline Hydrolysis Casein & Agar-milk & - & + \\
\hline Indole & Tryptone broth & + & + \\
\hline Nitrate reduction & Nitrate broth & - & - \\
\hline Glucose fermentation & Glucose broth & - & - \\
\hline Fermentation Lactose & Lactose broth & - & - \\
\hline $\begin{array}{l}\text { Fermentation } \\
\text { Sucrose }\end{array}$ & Sucrose broth & - & - \\
\hline $\begin{array}{l}\text { Fermentation } \\
\text { Mannitol }\end{array}$ & Mannitol broth & + & + \\
\hline Citrate & S. Citrate in agar & - & + \\
\hline Catalase & Leaning NA & - & - \\
\hline Urease & Urea broth & - & - \\
\hline $\mathrm{H}_{2} \mathrm{~S}$ & Agar $\mathrm{H}_{2} \mathrm{~S}$ & + & + \\
\hline Methyl red & & + & + \\
\hline Voges Proskauer & R-VP broth & + & + \\
\hline Hidrolysis Gelatin & Nutrient Gelatin & + & - \\
\hline Conclusion : & $\begin{array}{l}\text { Isolates of } 1 \\
\text { Isolates of } 2\end{array}$ & $\begin{array}{l}\text { Bacillus } \\
\text { Bacillus }\end{array}$ & $\begin{array}{l}\text { subtilis } \\
\text { flexus }\end{array}$ \\
\hline
\end{tabular}

Isolates symbionts Callyspongia $s p$ is a Gram-positive bacteria appear on staining with safranin, two isolates did not change color, indicating that the complex crystal violet and iodine remains bound to the cell wall and after added solvent $1 \% \mathrm{KOH}$, two isolates did not show the presence of mucus or say no late, (Pastra et al., 2012; Huda et al., 2012; Kurniawan, 2012; Murniasih et al., 2010).

Test citrate, (isolates 1) does not respond, indicating their carbon source other than citrate, and ( 2 isolates) positive reaction means isolates could use citrate as a carbon source. In the test gelatin, (isolates 1) positive means isolates have gelatinase enzyme and ( 2 isolates) means negative isolates did not have the enzyme gelatinase, (Huda, 2012; Djide et al., 2008; Lay, 1994).

Observations on test urease, (isolates 1 and 2) is negative means that the two isolates were not able to hydrolyze urea, meaning that both isolates have the enzyme urea, whereas in the test Voges two isolates (isolates 1 and 2) showed a positive result means that there are microorganisms in the second isolates capable implement 2.3 butanidiol fermentation. Methyl red test, two isolates reacted positively indicate that both can produce acid fermentation of glucose, (Djide et al., 2014; Huda, 2012; Lay, 1994).

Catalase test, (isolates 1 and 2) do not reacting, meaning that both isolates did not have the enzyme catalase which degrades hydrogen peroxide $\left(\mathrm{H}_{2} \mathrm{O}_{2}\right)$, while in the test fermentation using glucose, lactose, sucrose two isolates did not react, except test mannitol where the two isolates showed positive reaction, meaning the bacteria that grow in the liquid medium fermented sour the form, (Cappuchino et al., 2001; Lay, 1994). The characterization results test Gram staining and biochemical tests showed that both isolates the bacterial symbiont-containing enzyme, has the capability of fermentation and the ability to process carbon from the environment, so it is predicted that the bacterial symbiont sponge Callyspongia sp also able to use the enzyme constituent body to break down the components of hydrocarbon to components of simple organic compounds, (Marzuki et al., 2015b; Syakti et al., 2013; Aliyanta et al., 2011; Gan et al., 2009; Nugroho 2006;).

\section{CONCLUSION}

Sponges from Melawai Beach, Balikpapan is a species Callyspongia sp. Fractionation of components and composition of the biomass consists of skeleton (spicules and cell debris) reached $69.8 \%, 17.8 \%$ sponge cell fraction and $12.3 \%$ of bacteria pellets. The result of the isolation and purification of two isolates obtained microsymbiont sponge. Analysis of the phenotype through the test Gram stain both isolates were gram-positive bacteria, the results of biochemical tests, isolates of the bacteria species Bacillus subtilis forms in a large, beige-white colonies huddled together, while the isolates of the two species of Bacillus flexus form of jagged, elongated, white-purple and a separate colony.

\section{REFERENSI}

[1] Murniasih, T., Rasyid, A., 2010. Potensi bakteri yang berasosiasi dengan spons asal Barrang Lompo, Makassar sebagai sumber 
bahan antibakteri. J. Oseanologi dan Limnologi di Indonesia, 36(3):281-292

[2] Marzuki, I., Noor, A., Djide, N.M., La Nafie, N., 2014. Isolation and Identification on Degradator Bacterial of Petroleum waste which Symbionts with Sponge Callyspongis sp from Melawai Beach. Proceeding: International Confrence on the sciences (ICOS), 19-20 Nopember 2014, Makassar, ISBN : 9786027219809, pp. 493-503

[3] Gan, S., E.V. Lau, H.K. Ng., 2009. Remediation of Soils Contaminated with Polycyclic Aromatic Hydrocarbons (PAHs), Journal of Hazardous Materials, 172 : 532549

[4] Ismet, S.M., Soedharma, D., Effendi, H., 2011. Morphology and cell biomass of sponge Aaptos aaptos and Petrosia sp. J. Ilmu dan Teknologi Kelautan Tropis. Vol. 3 No. 2, p. 153-161

[5] Kurniawan, Allen, 2012. The isolation and identification of petrofilic bacteria from total petroleum hydrocarbons (TPH) residues under $1 \%(\mathrm{w} / \mathrm{w})$ of bioremediation prosess results. Prosiding Seminar Nasional Waste Management for Sustainable Urban Development, Surabaya, 21 Februari 2012

[6] Syakti, D. A., Yani, M., Hidayati, V.N., Siregar, S.A. Doumeng, P., I.M. Sudiana, M., 2013. The Bioremediation potential of hydrocarbonoclastic bacteria isolated from a Mangrove Contaminated by Petroleum Hydrocarbons on the Cilacap Coast, Indonesia. Journal Bioremediation, Vol. 17(1):11-20, ISSN: 1088-9868 online. DOI: 10.1080. 731446

[7] Bergquist, P.R., 2001. "Porifera (Spons)". Encyclopedia of Life Sciences. John Wiley \& Sons, Ltd. doi : 10.1038/npg.els.0001582

[8] Steindler, L., S. Beer, M. Ilan, 2002. Photosymbiosis in intertidal and subtidal tropical sponges. Symbiosis, Balaban Philadelphia, 33:1-11

[9] Marzuki, I., Noor, A., Djide, N.M., La Nafie, N., 2015, Molecular characterization of gene $16 \mathrm{~S}$ rRNA micro symbionts in sponge at Melawai Beach, East Kalimantan, Journal Marina Chimica Acta, 16 (1): 38-46

[10] Marzuki, I., Noor, A., Djide, N.M., La Nafie, N., 2015a, The potensi biodegradation hydrocarbons of petroleum sludge Waste by cell biomassa sponge Callyspongia $s p$, Journal Marina Chimica Acta, 16 (2): 11-20
[11] Huda, C., Salni, Melki, 2012. Penapisan Aktivitas dari Bakteri yang Berasosiasi dengan Karang Lunak Sarcophyton sp. Maspari Journal, 4(1):69-76

[12] Thakur, NL., and Weg Muller, 2004. Biotechnological Potensial of Marine Sponges. Jounal Current Science: (11) 86

[13] Lay B.W., 1994. Analisis Mikroba di Laboratorium. PT. Raja Grafindo Persada, Jakarta, $165 \mathrm{hlm}$.

[14] Kim, T.K., Hewavitharana, A.K., Shaw, P.N., and Fuerst, J.A., 2006. Discovery of a new source of rifamycin antibiotics in marine sponge actinobacteria by phylogenetic prediction. Journal Appl. Environ. Microbiol., Vol. 72: 2118-2125

[15] Nugroho, Astri. 2006. Biodegradasi Slugde Minyak Bumi dalam skala mikrokosmos, Simulasi sederhana kasian awal bioremediasi land treatment. Journal Makara, Sains. Vol. 10 No. 2:82-89

[16] Hooper, J.N,A., 1997. Guide to sponge collection and identification. Version Merch. Queensland Museum South Brisbane, Journal Queensland, Australia, 26-29

[17] Zocchi, E.G., Basile, C., Cerrano, G., Bavestello, M., Giovale, S.,Bruzzone, L., Guida, A., Carpaneto, R., Magrassi, and C. Usai, 2002. ABA-and cADPR-mediated effects on respiration and filtration downstream of the temperature-signaling cascade in sponges. Journal of Cell Science, 116:629-636

[18] Aliyanta, B., Sumarlin O.L., Mujab S.A., 2011. Penggunaan Biokompos dalam Bioremediasi Lahan Tercemar Limbah Minyak Bumi, Jurnal Valensi, 2011, Vol. 2 No.3:430-442

[19] Ruppert, E.E., Fox, R.S., and Barnes, R.D., 2004. Invertebrate Zoology (7 ed.). Brooks / Cole. hlm 76-97. ISBN 0-03-025982-7

[20] Silberhorn, A.M., V.Thiell and J.F. Imhoff, 2007. Abudance and bioactivity of cultured sponge associated bacteria from the Mediterranean Sea. Journal Microbial Ecology, 55:94-106

[21] Tam, N.F.Y and Wong, Y.S., 2008. Effectiveness of bacterial inoculum and mangrove plants on remediation of sediment contaminated with polycyclic aromatic hydrocarbons, Marine Pollution Bulletin, 57:716-728 
[22] Cappucino J. G., Sherman N., 2001. Microbiology Laboratory Manual. The Benjamin/ Cummings Publishing, Pearson Education Inc., San Francisco, USA:pg. 485

[23] Duchassaing \& Michelotti, 1864 Callyspongiidae - Wikipedia, the free encyclopedia,en.wikipedia.org/wiki/Callyspo ngiidae,www.nova.edu/ncri/soflasponge-gui de /sp_3.html

[24] Ekpo dan Udofia, 2008. Rate of biodegradation of crude oil by microorganism isolate from oil sludge environment. African journal of biotechnology, Vol.7 (24)

[25] Friederich, A.B., H. Maerkert, T. Fendert, J. Hacker, P. Proksch and U. Hentschel, 1999. Microbial diversity in he marine sponge Aplysina cavernicola (formely Verongia cavernicola) analyzed by fluorescence in situ hybridization (FISH). Journal Mar. Biol. 134: 46 1-470

[26] Gazave E., 2010. filogeni molekuler mengembalikan subdivisi supra-generik spons homoscleromorph (Porifera, homoscleromorpha). PLoS One. 2010 Dec 14; 5 (12): e14290. doi : 10.1371/journal .pone .0014290

[27] Jayardana, Trigunawan, 2006. Penilaian Terpadu Dampak Tumpahan Minyak Di Perairan Balikpapan : Studi Kasus Tumpahan Sludge Oil Dari Kapal Mt. panos, Tesis UI.

[28] Mahdiyah, D., Wahyudi, T. A., Mukti, H. B., 2012. Isolasi bakteri yang berasosiasi dengan spons Jaspis sp. penghasil Enzim Protease. Jurnal Bioscientiae, 2012, Vol. 9 (1) :1-7

[29] Murniasih. T., Yopi dan Budiawan. 2009. Biodegradasi Fenantrena oleh Bakteri Laut Pseudomonas sp KalP3b22 asal Kumai Kalimantan Tengah. Jurnal Makara, Sains, Vol. 13 No1: 77- 80

[30] Pastra. D. A., Melki, Surbakti H., 2012. Penapisan bakteri yang bersimbiosis dengan spons jenis Aplysina sp sebagai penghasil antibakteri dari perairan Pulau Tegal lampung. Maspari Journal, 4(1):77-82

[31] Setyadji, B and Panggabean, A.S., 2010. The effect of substrate and water depth on the growth of Callyspongia sp. in Jepara Waters. $J$. Bawal, Vol. 3. No.3 : www .aca demia.edu 15739745

[32] Vacelet, J., and Donadey. 1977. Electronmicroscope study of the association between methane-oxidizing bacteria and deep sea carnivorous cladorhizid sponge. Journal Mar. Ecol. Prog. Ser., 145:77-85

[33] Wahl, M., Jensen, P.R., Fenical, W., 1994. Chemical control of bacterial epibiosis on Ascidians. Journal Mar. Ecol. Prog. Ser., Vol. 110: 45-57

[34] Yani M. Dan Akbar Y. 2012. Diesel oil biodegradation process by mixed culture of hydrocarbon degrader bacteria. Jurnal Teknologi Industri Pertanian, Vol. 19 (1): 40-44

[35] Bagavananthem, S.G., 2010. Cyclodepsipeptides from marine sponges: Natural agents for drug research. Journal Marine Drugs, vol. 8: 810-834

[36] Djide, N. M., Sartini, 2008. Analisis Mikrobiologi Farmasi, Penerbit Press 21, ISBN: 979-320-127-7, Makassar, pp. 121133

[37] Djide, N. M., Sartini, 2014. Dasar-Dasar Mikrobiologi Farmasi, Penerbit Press 21, ISBN: 978-979-530-9, Makassar, pp. 167216

[38] Hentschel U., M. Schmid., M. Wagner, L. Fieseler, C. Gernert, and Hacker, 2001. Isolation and phylogenetic analysis of bacteria with antimicrobial activities from the Mediterranean sponges Aplysina aerophoba and Aplysina cavernicola. Journal FEMS Microbiol Ecol. vol. 35: 305312

[39] Lay, B.W., 1994. Analisis mikroba di laboratorium. Jakarta: PT Raja Grafindo Persada, Jakarta, pp. 167

[40] Li, Xuanzhen, Yucheng Wu, Xiangui Lin, Jing Zhang, Jun Zeng, 2012. Dissipation of polycyclic aromatic hydrocarbons (PAHs) in soil microcosms amended with mushroom cultivation substrate. Soil Biology \& Biochemistry Journal, vol. 47: 191-197

[41] Lin, Y., and L. X. Cai, 2008. PAHdegrading microbial consortium and its pyrene-degrading plasmids from mangrove sediment samples in Huian, China. Marine Pollution Bulletin, vol. 57: 703-706

[42] Liu Z, Shao Z. 2007. The diversity of alkane degrading bacteria in the enrichments with deep sea sediment of the South China Sea. $J$. Wei Sheng Wu Xue Bao., vol. 47: 869-873

[43] Obire, O., Akinde, S.B., 2011. In-situ physic-chemical properties of the deep Atlantic Ocean water colum and implications on heterotrophic bacterial 
distribution in the guff of Guines, Advances in applied Science Research, vol. 2 (2): 470482

[44] Lydia, M., Alfian, N., Tjodi, H., Nicole, de, V., 2014. Essential Metal $\mathrm{Zn}$ in Sponge Callyspongia aerizusa from Spermonde Archipelago, Advances in Biological Chemistry Journal, vol. 4: 86-90, http://dx.doi.org/10.4236/abc, 2014.41012

[45] Netty,S., Alfian, N., Nunuk, S., Nicole, de, V., 2014. A preliminary Effort to assign Sponge (Callyspongia $s p$ ) as trace metal biomonitor for $\mathrm{Pb}, \mathrm{Cd}, \mathrm{Zn}$, and $\mathrm{Cr}$, an enviromental persfective in hative gulf water Ambon, Advances in Biological Chemistry Journal, vol. 3: 549-552, http://dx.doi.org/10.4236/abc,2013.26062

[46] Shama. S.A., M.E. Moustafa, M.A. Gad, 2010. Removal of heavy metals $\mathrm{Fe}^{3+}, \mathrm{Cu}^{2+}$, $\mathrm{Zn}^{2+}, \mathrm{Pb}^{2+}, \mathrm{Cr}^{3+}$ and $\mathrm{Cd}^{2+}$ From Aquaeus Solutins by Using Eichornia Crassipes, Journal Electrochimica Acta, vol. 28 (2): 125-133 